Submitted to: Journal of Power Sources

Date: December 15, 2016 (originally submitted November 7, 2016)

\title{
Improved electrical power production of thermally regenerative batteries using a poly(phenylene oxide) based anion exchange membrane
}

\author{
Mohammad Rahimi ${ }^{1}$, Liang Zhu ${ }^{2}$, Kelly L. Kowalski ${ }^{1}$, Xiuping Zhu ${ }^{3,4}$, Christopher A. Gorski ${ }^{3}$, \\ Michael A. Hickner ${ }^{1,2,5}$, Bruce E. Logan ${ }^{3, *}$ \\ ${ }^{1}$ Department of Chemical Engineering, The Pennsylvania State University, University Park, PA 16802, USA \\ ${ }^{2}$ Department of Materials Science and Engineering, The Pennsylvania State University, University Park, PA 16802, \\ USA \\ ${ }^{3}$ Department of Civil and Environmental Engineering, The Pennsylvania State University, University Park, PA \\ 16802, USA \\ ${ }^{4}$ Department of Civil and Environmental Engineering, Louisiana State University, Baton Rouge, LA 70803, USA \\ ${ }^{5}$ Department of Chemistry, The Pennsylvania State University, University Park, PA 16802, USA \\ *Corresponding Author. Telephone: +1 814863 7908. Fax: +1 814863 7304. E-mail: blogan@psu.edu.
}

\begin{abstract}
Thermally regenerative ammonia-based batteries (TRABs) can be used to harvest low-grade waste heat as electrical power. To improve TRAB performance, a series of quaternary ammonium-functionalized poly(phenylene oxide) anion exchange membranes (BTMA-AEMs) were examined for their impact on performance relative to a commercial AEM (Selemion AMV). The synthesized AEMs had different degrees of functionalization (DF; 25\% and 40\%), and thicknesses (50, 100 and $150 \mu \mathrm{m})$. Power and energy densities were shown to be a function of both DF and membrane thickness. The power density of TRAB increased by $31 \%$ using a BTMA AEM (40\% DF, $50 \mu \mathrm{m}$ thick; $106 \pm 7 \mathrm{~W} \mathrm{~m}^{-2}$ ) compared to the Selemion $\left(81 \pm 5 \mathrm{~W} \mathrm{~m}^{-2}\right)$. Moreover, the energy density increased by $13 \%$ when using a BTMA-based membrane $\left(25 \% \mathrm{DF}, 150 \mu \mathrm{m}\right.$ thick; $\left.350 \mathrm{Wh} \mathrm{m}^{-3}\right)$ compared to the Selemion membrane $\left(311 \mathrm{Wh} \mathrm{m}^{-3}\right)$. The thermal-electric conversion efficiency improved to $0.97 \%$ with the new membrane compared to $0.86 \%$ for the Selemion. This energy recovery was $7.0 \%$ relative to the Carnot efficiency, which was 1.8
\end{abstract}


times greater than the highest previously reported value of a system used to capture low-grade waste heat as electricity.

Keywords: waste heat; thermally regenerative battery; anion exchange membrane; energy harvesting; thermal efficiency

\section{Introduction}

A significant amount of low-grade waste heat (temperature $<130{ }^{\circ} \mathrm{C}$ ), approximately half of the current U.S.A energy demand $\left(2.9 \times 10^{13} \mathrm{kWh}\right.$ in 2013$)$, is generated at industrial plants in the U.S. [1-4]. In recent years, harvesting low-grade waste heat as electrical power has drawn increasing attention due to its vast potential and availability often at locations where electrical power is needed [5-8]. One method of direct waste-heat-to-electricity energy conversion is solidstate thermoelectrics based on p- and n-type semiconductor materials [9-11], but high costs, long-term unreliability, and lack of capacity for energy storage have limited applications of these technologies [11]. Liquid-based thermoelectrochemical cells (TECs) that utilize the temperature dependence of electrochemical redox potentials to drive an electrochemical cell offer an alternative, potentially less expensive and scalable system for direct thermal-electric energy conversion, with opportunities for energy storage [12-14]. While a considerable amount of progress has been achieved during recent years in developing new types of TECs, their power densities and thermal-electricity energy conversion efficiencies need to be improved to make them commercially viable [15].

A thermally regenerative ammonia battery (TRAB) was recently developed as a new approach to harvest low-grade waste heat as electrical power that improved power densities compared to existing TECs [16]. In a TRAB, two copper electrodes are exposed to a copper(II) 
electrolyte, such as copper(II) nitrate. The two electrode chambers are separated by a membrane, as discussed below. Electrical power is produced by adding ammonia to the anolyte, but not to the catholyte (Figure S1a). The ammonia complexes copper(II) and generates a potential difference between the electrodes according to the following reactions:

$$
\begin{array}{ll}
\text { Cathode: } \mathrm{Cu}^{2+}{ }_{(\text {aq })}+2 \mathrm{e}^{-} \rightarrow \mathrm{Cu}_{(\mathrm{s})} & E^{0}=+0.340 \mathrm{~V} \\
\text { Anode: } \mathrm{Cu}_{(\mathrm{s})}+4 \mathrm{NH}_{3(\mathrm{aq})} \rightarrow \mathrm{Cu}\left(\mathrm{NH}_{3}\right)_{4}{ }^{2+}{ }_{(\mathrm{aq})}+2 \mathrm{e}^{-} & E^{0}=-0.04 \mathrm{~V}
\end{array}
$$

where $E^{0}$ is the standard reduction potential vs. the standard hydrogen electrode (SHE) [17]. After discharging the cell (Figure S1b), ammonia is separated from the anolyte using conventional separation technologies, such as distillation, that utilize low-grade waste heat (Figure S1c) $[18,19]$. The distilled ammonia is then added to the other electrolyte chamber for the next discharge cycle (Figure S1d). By switching the compartment that contains ammonia, copper is re-deposited onto the formerly dissolved electrode, and the other electrode dissolves (Figure S1e). This alternating cycle of electrode dissolution/deposition allows the Cu electrodes to be maintained in closed-loop cycles, and waste heat energy is converted to electricity through ammonia distillation (Figure S2). A maximum power density of $80 \mathrm{~W} \mathrm{~m}^{-2}$-electrode area with a thermal-electricity conversion efficiency of $0.86 \%$ (6.2\% relative to the Carnot efficiency), has been achieved using a TRAB containing a commercial anion exchange membrane (AEM) $[16$, $19,20]$.

In a TRAB, an AEM is used to separate the cathode and anode compartments and facilitate ion conduction to balance the internal charge transfer through transport of anions such as nitrate and hydroxide between the electrolyte chambers. In addition, the AEM minimizes self-discharge by reducing the transfer of either ammonia or positively-charged copper(II) amine complexes 
from the anolyte to the catholyte, and copper(II) ions from the catholyte to the anolyte (Figure 1a). However, the transfer of hydroxide from the alkaline anode chamber $(\mathrm{pH}=9.7)$ to the acidic cathode chamber $(\mathrm{pH}=2.6)$ results in a shift in the $\mathrm{NH}_{4}{ }^{+} / \mathrm{NH}_{3}$ acid/base equilibrium towards $\mathrm{NH}_{3}$ formation in the cathode chamber (Eqn. S1). This formation of $\mathrm{NH}_{3}$ in the cathode chamber results in an unfavorable chemical consumption (Eqns. S2-S5) instead of electrochemical consumption of copper ions (Eqn. 1; Figure 1b). In previous TRAB tests using a commercial AEM (Selemion AMV), substantial self-discharge occurred that limited the electrical energy production $[16,20]$. In addition, in our recent study on copper removal from water using an adaption of a TRAB, it was shown that the cell self-discharge limited the effectiveness of copper removal at low initial concentrations of copper in the catholyte $(<0.01 \mathrm{M})[21]$.
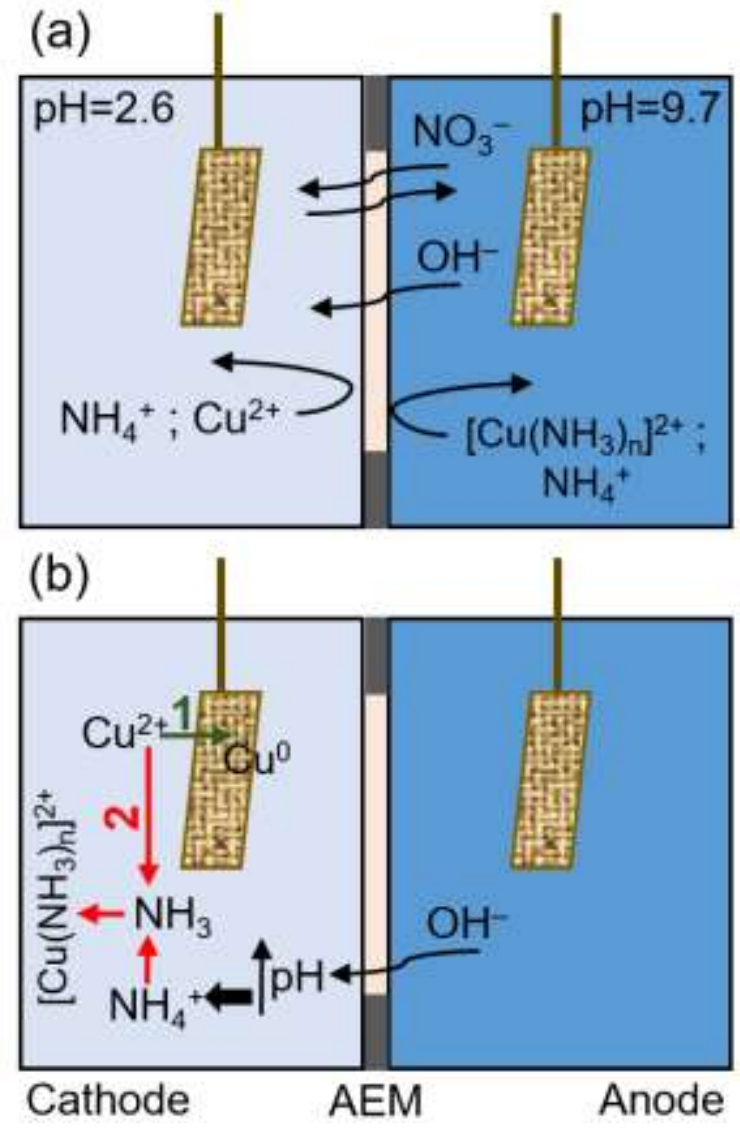

Figure 1. Schematic of the TRAB with an anion exchange membrane (AEM): (a) AEM prevents transfer of both $\mathrm{NH}_{3}$ and positively charged species, (b) higher transfer of $\mathrm{OH}^{-}$through the 
membrane causes a higher rate of TRAB self-discharge by chemical consumption of copper ions $\left(\right.$ reaction $2 ; \mathrm{Cu}^{2+}+\mathrm{n} \mathrm{NH}_{3} \rightarrow \mathrm{Cu}\left(\mathrm{NH}_{3}\right)_{\mathrm{n}}{ }^{2+}$ ).

Here, we hypothesized that by varying the AEM's thickness and ion exchange capacity (IEC), we could reduce cell self-discharge and maximize energy production. To test this hypothesis, anion exchange membranes were synthesized using poly(phenylene oxide) (PPO) backbones with pendant benzyltrimethyl ammonium cations (BTMA). These types of membranes were previously shown to be more efficient, potentially less expensive, and more chemically and thermally stable than commercially available membranes [22-26]. The performance of these PPO-based AEMs were evaluated in a TRAB cell in terms of power density, membrane resistance, energy density, cell self-discharge, and thermal-electricity efficiency based on comparisons to the AEM used in previous research (Selemion AMV). Since AEMs in TRAB are exposed to solutions that have low $\mathrm{pH}$ (2.6 for the cathode) or high $\mathrm{pH}(9.7$ for the anode), the stabilities of the fabricated membranes were examined in strongly acidic or alkaline solutions.

\section{Experimental Section}

\subsection{Membrane Preparation}

Brominated PPO polymers, having a degree of functionalization (DF) of 25 and $40 \mathrm{~mol} \%$ of the repeat units on the backbone with one benzyl bromide group (Br-PPOx; $x=25$ or 40) were synthesized as previously described $[27,28]$. The molecular weight of PPO was $30000 \mathrm{~g} \mathrm{~mol}^{-1}$, while that of brominated PPO was $39000 \mathrm{~g} \mathrm{~mol}^{-1}$. Brominated PPO with a DB of $40 \%(\mathrm{Br}-$ PPO40; $2.0 \mathrm{~g}$ ) was dissolved in $20 \mathrm{~mL}$ of N-methyl-pyrrolidone (NMP; $97 \%$; Sigma-Aldrich), and $3.2 \mathrm{~mL}$ of aqueous trimethylamine ( $45 \mathrm{wt} \%$; $\geq 99 \%$; Sigma-Aldrich). The mixture was stirred for $24 \mathrm{~h}$ at room temperature, and poured into $100 \mathrm{~mL}$ of toluene (99.8\%; Sigma-Aldrich) 
or hexane (95\%; Sigma-Aldrich) to precipitate the polymer. The product was filtered and washed with toluene or hexane several times. The dark yellow mixture which was produced with a yield of $87 \%$ was dried at $50{ }^{\circ} \mathrm{C}$ overnight under vacuum. The formed powder $(2 \mathrm{~g})$ was then dissolved in NMP (20 mL), and an appropriate amount of the solution, depending on the membrane final thickness, was cast onto a leveled glass plate. The cast solution was dried at 82 ${ }^{\circ} \mathrm{C}$ under ambient pressure for $24 \mathrm{~h}$ followed by vacuum drying for another $24 \mathrm{~h}$ at $80{ }^{\circ} \mathrm{C}$ to obtain a B40-y membrane, where B40 refers to the degree of functionalization of a BTMA-based membrane and $y$ stands for the membrane thickness (Figure S3). All other Bx-y membranes were prepared using similar procedures as described above.

In order to remove the solvent form the polymer during the membrane preparation, samples were dried at various temperatures to the point at which the mass of the polymers or membranes were constant. The drying temperatures depend on the specific solvents which were used. For the low boiling point solvents such as hexanes and toluene, lower drying temperatures $\left(50{ }^{\circ} \mathrm{C}, 60\right.$ ${ }^{\circ} \mathrm{C}$ ) were sufficient to remove the solvents under vacuum. To remove NMP which has a higher boiling point, a higher drying temperature $\left(80^{\circ} \mathrm{C}\right)$ was employed under vacuum.

\subsection{Membrane Characterization and Measurements}

To identify the membrane structure, ${ }^{1} \mathrm{H}$ NMR spectra were recorded at $300 \mathrm{MHz}$ on a spectrometer (AV 300, Bruker, Billerica, MA) using DMSO- $\mathrm{d}_{6}$ as the solvent. Water uptake was measured after drying the membrane at $60{ }^{\circ} \mathrm{C}$ under vacuum for $24 \mathrm{~h}$. The dried membrane was immersed in water and periodically weighed on an analytical balance until a constant mass was obtained, giving the mass-based water uptake. Water uptake (WU) was calculated as $W U=$ $\left(m_{\text {hyd }}-m_{0}\right) / m_{0}$, where $m_{\text {hyd }}$ is the hydrated sample mass and $m_{0}$ is the dry sample mass. To calculate the titrated gravimetric IEC values, membranes in the $\mathrm{OH}^{-}$form were immersed in 50 
$\mathrm{mL}$ of $0.01 \mathrm{M} \mathrm{HCl}$ standard solution for $24 \mathrm{~h}$. Then, the solutions were titrated with a standardized $\mathrm{NaOH}(0.01 \mathrm{M})$ solution to $\mathrm{pH}=7$. Subsequently, the samples were washed and immersed in deionized water for $24 \mathrm{~h}$ to remove the residual $\mathrm{HCl}$, and then dried under vacuum at $50{ }^{\circ} \mathrm{C}$ overnight and weighed to calculate the dry masses in the $\mathrm{Cl}^{-}$form. The IEC of the membranes was calculated as:

$$
I E C=\frac{n_{i\left(H^{+}\right)^{-n}} f\left(H^{+}\right)}{m_{d r y}(C l)}
$$

where $m_{d r y(C l)}$ is the mass of dry membranes, $n_{i\left(H^{+}\right)}$is the initial amount of $\mathrm{H}^{+}$in the $\mathrm{HCl}$ solution, $n_{f\left(H^{+}\right)}$is the final amount of $\mathrm{H}^{+}$in the $\mathrm{HCl}$ solution.

Electrochemical impedance spectroscopy (EIS; VMP3, Bio-Logic) was used to quantify different components of the resistances of the various membranes in the TRAB system. All EIS tests were measured over a frequency range of $100 \mathrm{kHz}$ to $0.1 \mathrm{~Hz}$ with a sinusoidal amplitude of $10 \mathrm{mV}$. The batteries were discharged at $0.2 \mathrm{~V}$ for $5 \mathrm{~min}$ with stable current production before imposing a sinusoidal perturbation to achieve a pseudo steady state. The EIS spectra were fitted into a simplified Randles equivalent circuit to identify the membrane resistance (Figure S4; Eqn. S6, S7).

Since the membrane in the TRAB was continuously in contact with acidic (catholyte $\mathrm{pH}=2.6$ ) and alkaline (anolyte $\mathrm{pH}=9.7$ ) solutions, the stabilities of the fabricated membranes were separately tested in acidic or alkaline conditions. Two membranes (B24 and B40) were immersed in similar solutions to that of the catholyte $\left(0.1 \mathrm{M} \mathrm{Cu}\left(\mathrm{NO}_{3}\right)_{2}, 5 \mathrm{M} \mathrm{NH}_{4} \mathrm{NO}_{3}\right)$ or anolyte $(0.1 \mathrm{M}$ $\mathrm{Cu}\left(\mathrm{NO}_{3}\right)_{2}, 5 \mathrm{M} \mathrm{NH}_{4} \mathrm{NO}_{3}, 2 \mathrm{M} \mathrm{NH}_{3}$ ) for a period of time (50 h) chosen to match about 30 cycles of the battery discharge, at room temperature. The membranes were then soaked in deionized water for $24 \mathrm{~h}$, and then their performance was examined based on polarization tests. The durability of the fabricated membranes was also tested to evaluate the dry form stability after 
long-term storage. Membranes were stored dry for 1 year in a constant temperature room (30 ${ }^{\circ} \mathrm{C}$ ), and then their performance was compared to newly fabricated membranes with the same IEC and thickness.

\subsection{TRAB Construction and Operation}

The TRAB was constructed as previously described $[16,20]$. The battery consisted of a cathode and an anode chamber, each $4 \mathrm{~cm}$ long and $3 \mathrm{~cm}$ in diameter, separated by an AEM (either Selemion AMV with a thickness of $100 \mu \mathrm{m}$, Asashi glass, Japan; or the fabricated membranes) with a projected surface area of $7 \mathrm{~cm}^{-2}$. Two $0.8 \mathrm{~cm} \times 2 \mathrm{~cm}$ pieces of copper mesh $(50 \times 50 \mathrm{mesh}$; McMaster-Carr, $\mathrm{OH})$ connected by copper wire were used as the electrodes. To monitor the electrode potentials, $\mathrm{Ag} / \mathrm{AgCl}$ reference electrodes (+0.211 V vs. SHE; RE-5B; BASi) were inserted $1 \mathrm{~cm}$ away from each electrode (2 $\mathrm{cm}$ away from the membrane). The catholyte was mixed using a magnetic stirrer $(6.4 \times 15.9 \mathrm{~mm}$; VWR $)$ at $600 \mathrm{rpm}$.

The electrolytes were prepared by making a $0.1 \mathrm{M}$ of $\mathrm{Cu}\left(\mathrm{NO}_{3}\right)_{2}$ (Sigma-Aldrich) solution with $5 \mathrm{M} \mathrm{NH}_{4} \mathrm{NO}_{3}$ as the supporting electrolyte to increase conductivity. Ammonium hydroxide (2 M final concentration; $5 \mathrm{~N}$ solution, Sigma-Aldrich) was added only to the anolyte to form the copper ammonia complex and create a potential difference between the cathode and anode chambers.

\subsection{TRAB Performance Evaluation}

Polarization tests were performed using a data acquisition system (Agilent 34972A, Santa Clara, CA) to measure the cell voltage $(U)$, and each electrode potential at room temperature. External resistances were switched every $3 \mathrm{~min}$ from open circuit to $1.4 \Omega$ in decreasing order (i.e. 21.4 $\Omega, 11.5 \Omega, 6.4 \Omega, 4.4 \Omega, 3.4 \Omega, 2.5 \Omega, 1.4 \Omega$; total $24 \mathrm{~min})$. Both current density $\left(i=U / R A, \mathrm{~A} \mathrm{~m}^{-}\right.$

2; $i$ : current density, $U=$ voltage, $R=$ external resistance, and $A=$ surface area), and power 
density $\left(P=U^{2} / R A, \mathrm{~W} \mathrm{~m}{ }^{-2}\right)$ were normalized using a single electrode projected surface area $(1.6$ $\mathrm{cm}^{2}$ ) [29]. For discharge tests, the cell was operated with a fixed external resistance that produced the highest power (based on the polarization data), until the cell voltage decreased to $10 \mathrm{mV}$. Using the discharge test data, the energy density, normalized to the total electrolyte volume $\left(E, \mathrm{Wh} \mathrm{m}^{-3}\right)$, was calculated as $E=\int U I t / V_{t}$, where $U$ is the voltage $(\mathrm{V}), I$ the current (A), $t$ the cycle time (h), and $V_{t}$ the volume of the reactor (56 mL; 2 chambers with $28 \mathrm{~mL}$ each).

Copper electrochemical consumption $(C E C)$ tests were performed to identify the fraction of $\mathrm{Cu}^{2+}$ deposition $\left(\mathrm{Cu}^{2+} \rightarrow \mathrm{Cu}^{0}\right)$ that was due to the electrochemical reaction relative to the total amount of $\mathrm{Cu}^{2+}$ depletion (due to electrochemical and chemical reactions):

$$
\operatorname{CEC}(\%)=\frac{\left(m_{f}-m_{0}\right)}{C_{i} M V_{c}} \times 100
$$

where $m_{0}$ and $m_{f}$ are electrode masses before and after the discharge test, $C_{i}$ is the initial concentration of $\mathrm{Cu}(\mathrm{II})$ in the catholyte $(0.1 \mathrm{M}), M$ is the molecular weight of copper (63.55 $\mathrm{g}$ $\left.\mathrm{mol}^{-1}\right)$, and $V_{c}$ is the volume of cathode chamber $(28 \mathrm{~mL})$. Cathodic coulombic efficiency $(C C E)$ was calculated as the ratio between actual produced charge to the theoretical charge based on the mass change of the electrode to find the dominant electrochemical reaction in the catholyte, as:

$$
\operatorname{CCE}(\%)=\frac{\left(m_{f}-m_{0}\right)}{\frac{Q M}{2 F}} \times 100
$$

where $Q$ is the total charge transferred $\left(Q=\int I t, \mathrm{C}\right)$, and $F$ is Faraday's constant $\left(96485 \mathrm{C} \mathrm{mol}^{-1}\right)$. For the cathode electrode, the mass was measured using an analytical balance with a precision of 0.0001 gram, and the value was used for either the $C E C$ or $C C E$ calculations.

After discharging the TRAB, the battery was recharged by separating ammonia from the anolyte and re-dissolving it in the catholyte (Figure S1c, d). In practice, low-grade waste heat $\left(<130{ }^{\circ} \mathrm{C}\right)$ could be used for this process, for example by using a distillation column with a reboiler temperature of $70.4{ }^{\circ} \mathrm{C}$ and a condenser temperature of $43.3^{\circ} \mathrm{C}$ (Figure S2). Previous 
simulation results indicated that $97 \%$ of ammonia could be recovered during the designed separation process $[16,20]$. The thermal energy efficiency $(\eta)$ was calculated as the ratio between the discharge energy and the required thermal energy for electrolyte regeneration ( $\eta=$ actual discharge energy/required thermal energy).

\section{Results and Discussion}

\subsection{Membranes characterization}

The polymer structure of the fabricated BTMA-based AEMs was characterized by ${ }^{1} \mathrm{H}$ NMR spectroscopy. The peaks at 3.1 and $4.4 \mathrm{ppm}$ for benzyltrimethylammonium indicated that the quaternary ammonium group was successfully formed (Figure 2) [24]. Using the ${ }^{1} \mathrm{H}$ NMR spectroscopy, it was also confirmed that the purity of the synthesized polymer was higher than 97\%. The IEC of Selemion was $1.93 \mathrm{mmol} \mathrm{g}^{-1}$ which was similar to the previously reported value $\left(\sim 1.9 \mathrm{mmol} \mathrm{g}^{-1}\right.$ ) (Table 1) [30, 31]. Raising the degree of functionalization from $25 \%$ (B25) to $40 \%$ (B40) increased the IEC from 1.82 to $2.04 \mathrm{mmol} \mathrm{g}^{-1}$. This result was in agreement with the previous investigations which indicated that IEC is a function of functionalization degree $[24,32,33]$. The water uptake measured for the Selemion AMV (20 wt \%) was significantly lower than that of the fabricated membranes ( $63 \%$ for B25; $80 \%$ for B40). Although the exact structure of the Selemion is not available, it is likely that either the functionalized head group or the polymer backbone of the Selemion was less hydrophilic than that of the BTMAbased AEM. Water uptake increased with the IEC, mainly because the benzyltrimethyl ammonium group on the polymer backbone enhanced the hydrophilicity of the fabricated membrane [33, 34].

Table 1. IEC and water uptake of the Selemion compared to that of the B25 and B40 AEMs, all with a thickness of $100 \mu \mathrm{m}$. 


\begin{tabular}{|c|c|c|}
\hline Sample & $\begin{array}{c}\text { IEC } \\
\left(\mathbf{m m o l ~}^{-\mathbf{1}}\right)\end{array}$ & Water uptake (wt \%) \\
\hline Selemion & 1.93 & $20 \pm 2$ \\
\hline B25 & 1.82 & $63 \pm 4$ \\
\hline B40 & 2.04 & $80 \pm 7$ \\
\hline
\end{tabular}

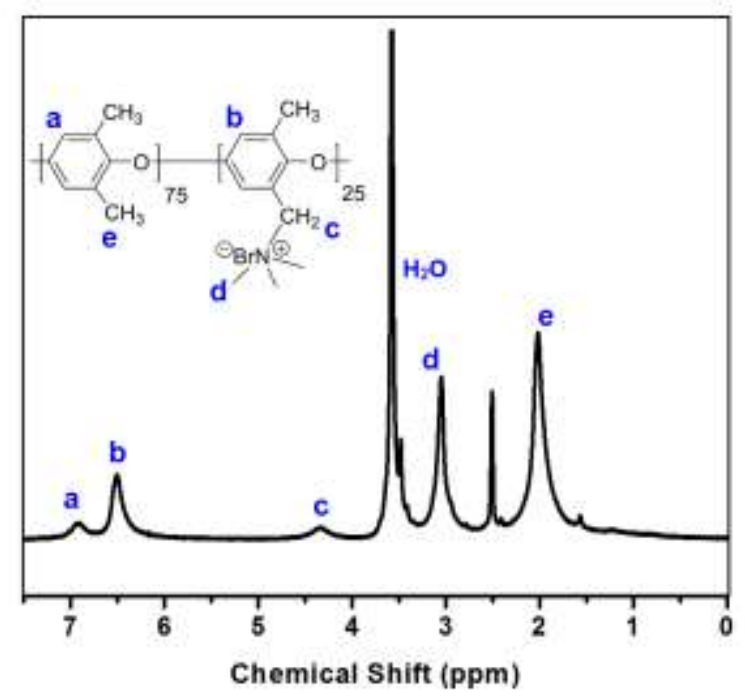

Figure 2. ${ }^{1} \mathrm{H}$ NMR of B25 in DMSO- $\mathrm{d}_{6} / \mathrm{D}_{2} \mathrm{O}$ (10:1 wt:wt).

Membranes were analyzed by EIS to compare their operational resistances. The resistance decreased with an increase in IEC. For example, for the $100 \mu \mathrm{m}$ thick membranes the resistance was $1.61 \Omega$ for the B25-100 with an IEC of $1.82 \mathrm{mmol} \mathrm{g}^{-1}$, and $1.14 \Omega$ for B40-100 which had a higher IEC of $2.04 \mathrm{mmol} \mathrm{g}^{-1}$ (Figure 3). In general, the membranes showed the expected trend that the resistance increased with membrane thickness [23]. On average, the resistance of the B40-100 membrane appears to be higher than that of the B40-150, but the difference was not significant (Student's t-test; $\mathrm{p}=0.15$ ). Similarly, the difference between the resistances of B25100 and B25-150 was not significant $(\mathrm{p}=0.40)$. 


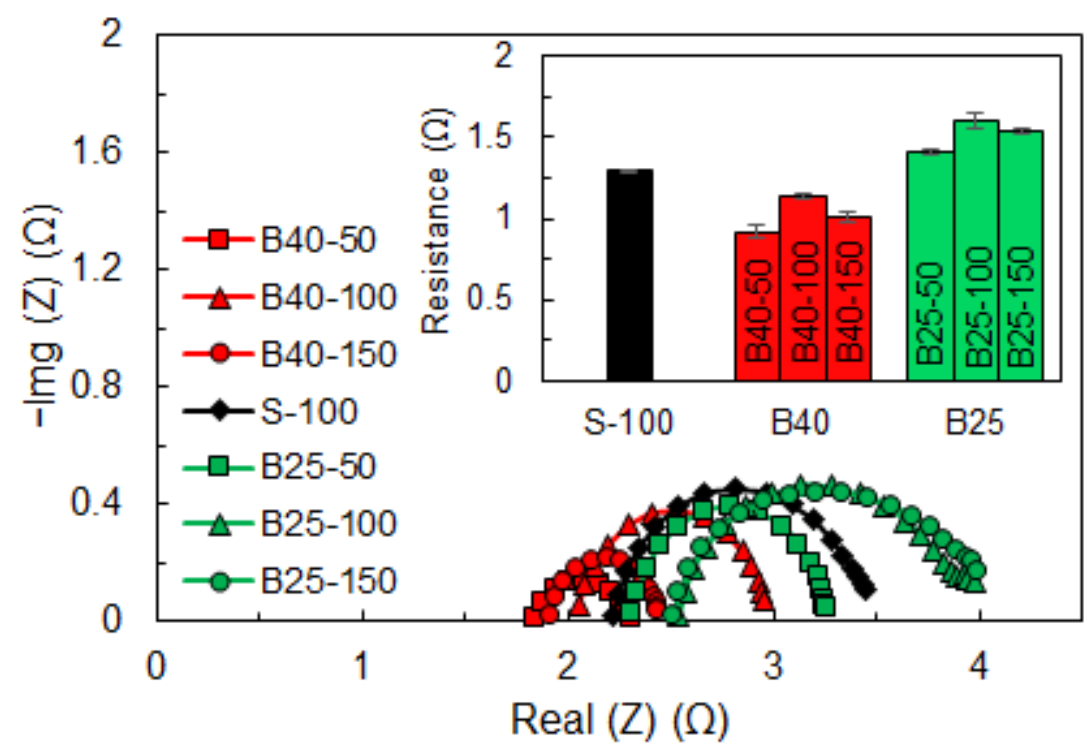

Figure 3. Nyquist plots of the whole cell impedance at $0.2 \mathrm{~V}$. The inserted figure indicates the membrane resistance obtained by fitting the Nyquist plots to the equivalent simplified Randles circuit for the TRABs with different AEMs (Fig. S4). The membrane resistances were calculated by subtracting the solution resistance from the sum of the solution and membrane resistance (the left $x$-intercepts in the Nyquist plot).

\subsection{Power production of TRAB operated with different AEMs}

Performance of the membranes was evaluated based on maximum power densities calculated from polarization tests. All three B40 membranes had power densities greater than those using the B25 or Selemion membranes. For each type of membrane, the maximum power density was inversely related to membrane thickness. For the B40 membranes, the maximum power density was $106 \pm 7 \mathrm{~W} \mathrm{~m}^{-2}$ for the $50 \mu \mathrm{m}$ thick membrane, and $89 \pm 5 \mathrm{~W} \mathrm{~m}^{-2}$ for the $150 \mu \mathrm{m}$ thick membrane. The same trend in power with membrane thickness was observed for B25 membranes. Lowering the IEC reduced the power production, where $95 \pm 6 \mathrm{~W} \mathrm{~m}^{-2}$ was produced for the B40-100 membrane compared to $70 \pm 4 \mathrm{~W} \mathrm{~m}^{-2}$ for the $\mathrm{B} 25-100$ membrane. Compared to the commercial Selemion membrane, power density could be increased by up to $\sim 30 \%$ with the B40-50 membrane (Figure 4a). 

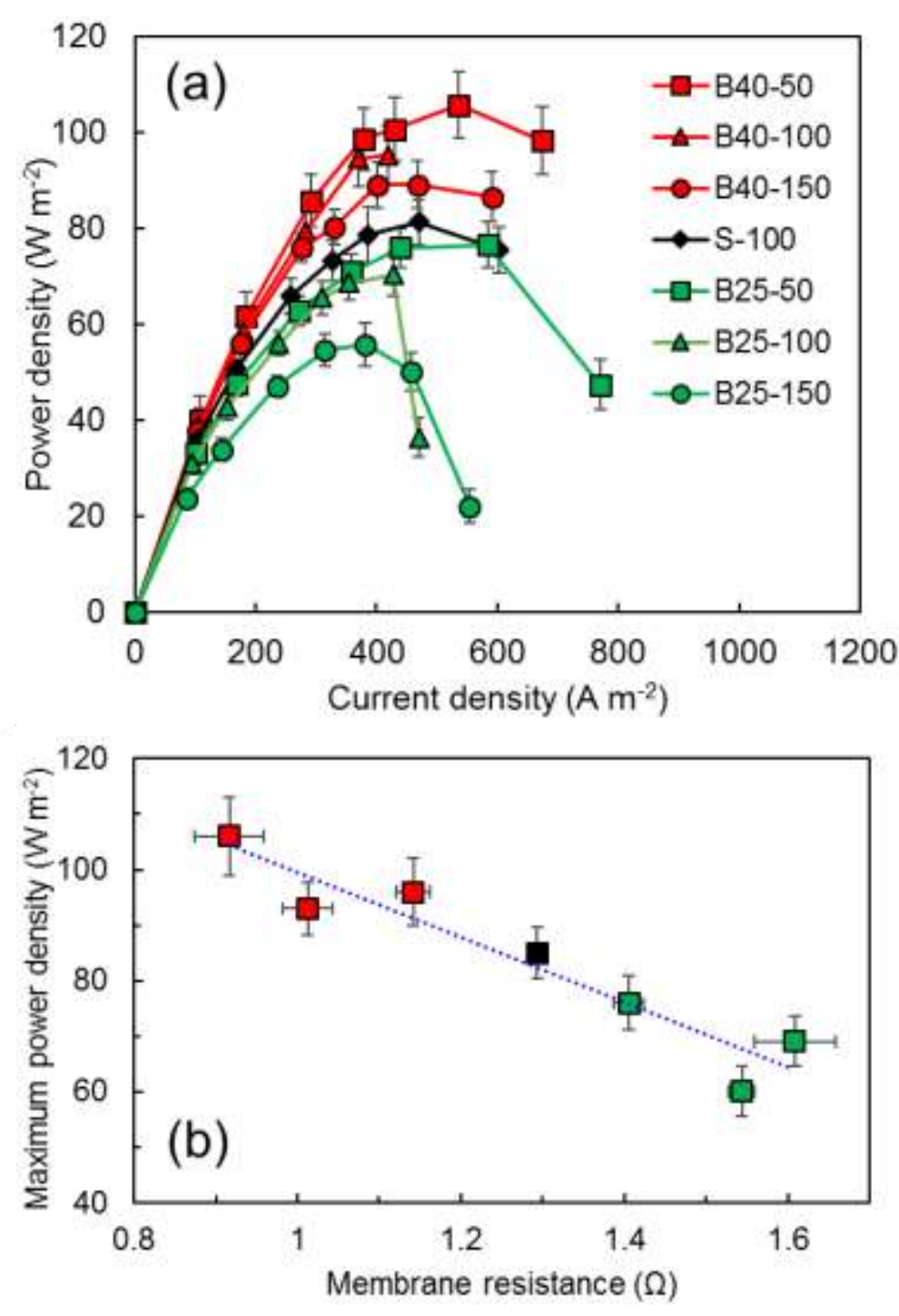

Figure 4. (a) Power densities produced by TRABs operated with different AEMs, (b) maximum power density as a function of membrane resistance (red: B40s; black: Selemion; green: B25s). The data were well fitted to a linear regression model with a $\mathrm{R}^{2}$ of 0.904 , and a $\mathrm{p}$-value (the significance of the slope) of less than 0.01 .

For all of the membrane samples, we examined whether the power densities were a significant function of the membrane resistance. The maximum power density significantly 
increased inversely with membrane resistance $\left(\mathrm{R}^{2}=0.90, \mathrm{p}<0.01\right)$ (Figure $\left.4 \mathrm{~b}\right)$. Lowering the membrane resistance, which can be achieved by increasing the IEC or decreasing the thickness, facilitated the anion transfer rate through the AEM, resulting in a lower cell ohmic resistance and a higher power production.

\subsection{Discharge/charge performance of TRAB with different AEM}

In order to evaluate energy production of the TRABs using the different AEMs, electrical energy generation was examined over a complete discharge cycle, at the external resistance that produced the maximum power in the polarization test. For the fabricated membrane with a higher IEC (B40), the power was greater than that obtained using the Selemion membrane, with the battery fully discharged over a shorter period of time. When the IECs of the membrane were lower, for example for the B25-100 sample, the cell discharge time was similar to that obtained using a Selemion membrane (155 min for B25-100; 150 min for Selemion). However, in this case, the B25-100 system produced a higher power density compared to Selemion membrane. Increasing the membrane thickness slightly enhanced the discharge time. For example, the B4050 TRAB was discharged for $110 \mathrm{~min}$, while that of the B40-100 TRAB was 120 min (Figure 5a).

The energy densities produced by the TRABs operated with B40-50 and B40-100 AEMs (high IEC) were lower than that obtained with the Selemion membrane. However, for the membranes with a lower IEC (i.e. B25), the energy densities were larger than that a TRAB with the Selemion membrane. The highest energy density obtained was $350 \mathrm{Wh} \mathrm{m}^{-3}$ using the B25150 membrane, which was $13 \%$ higher than that with the Selemion membrane (Figure $5 b$ ). Energy densities decreased with an increase in the IEC, although there was limited data for this comparison, but no significant relationship to the membrane resistance (Figure 6). 

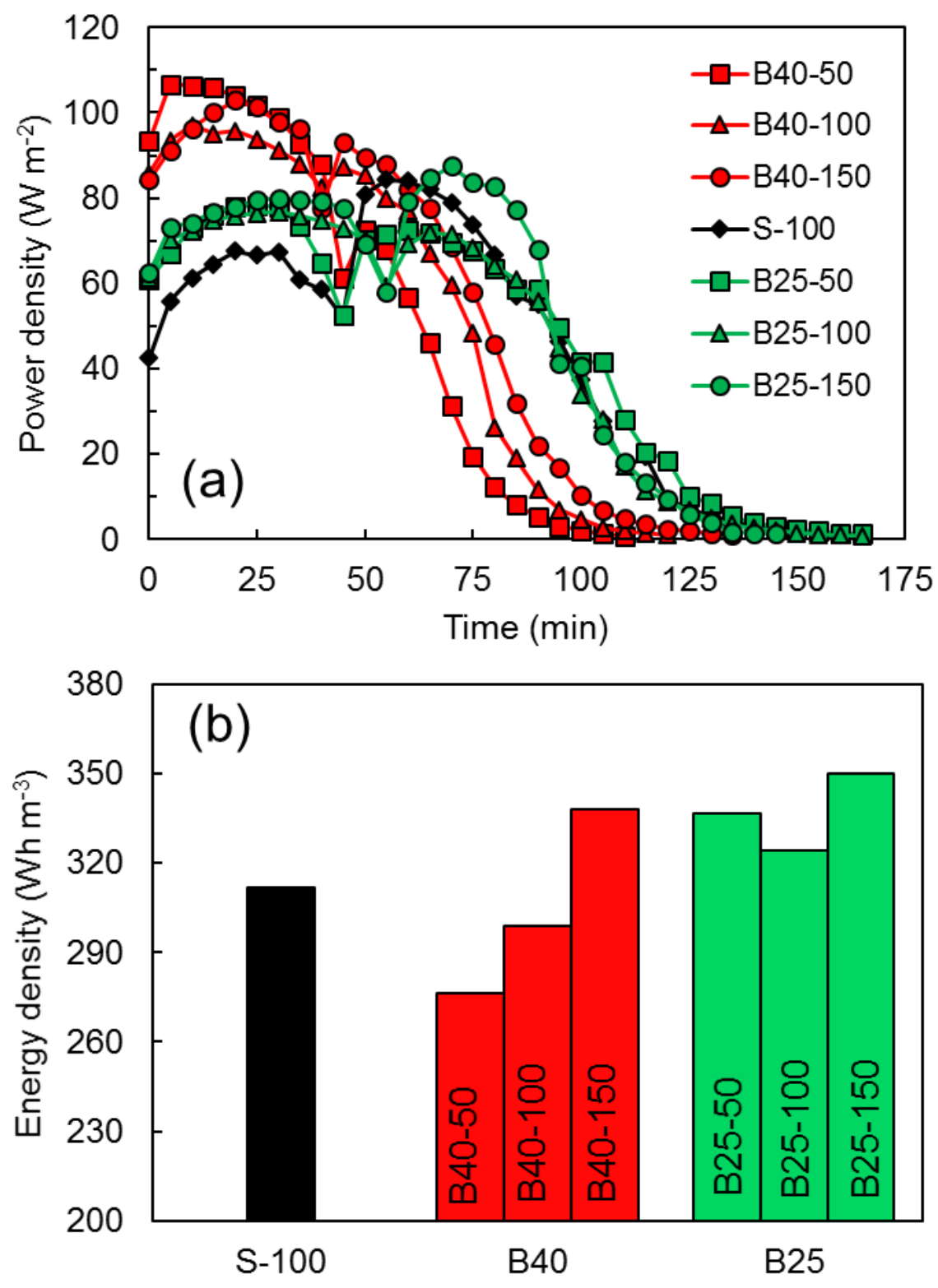

Figure 5. (a) The discharge performance, (b) electrical energy density of TRABs with Selemion (S-100), B40, and B25 AEMs. The initial electrolyte contained $0.1 \mathrm{M} \mathrm{Cu}(\mathrm{II}), 5 \mathrm{M}$ $\mathrm{NH}_{4} \mathrm{NO}_{3}$, and the anolyte also contained $2 \mathrm{M} \mathrm{NH}_{3}$. The sudden small drops on power density after 40-60 minute was due to the anode replacement. 

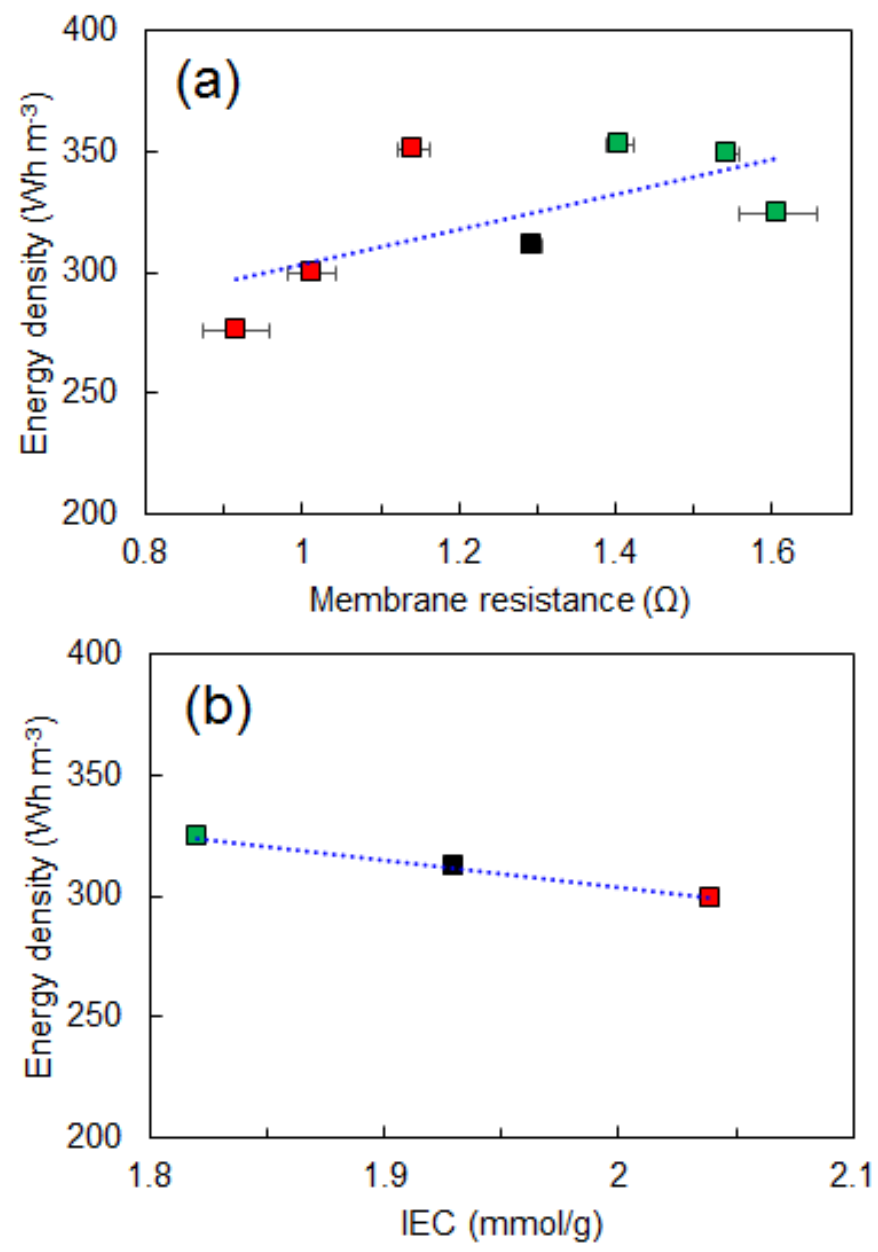

Figure 6. TRAB energy density as a function of (a) membrane resistance with a $\mathrm{R}^{2}$ of 0.417 , (b) membrane IEC with a $\mathrm{R}^{2}$ of 0.999 , and a p-value of less than 0.01 (red: B40s; black: Selemion; green: B25s). The data showed the energy density was controlled by the membrane IEC and not the resistance.

The final catholyte $\mathrm{pH}$ increased with the membrane IEC. For example, after 90 min of cell discharge, $\mathrm{pH}$ of the catholyte for the TRAB with the $\mathrm{B} 25-100$ membrane increased from 2.6 to 6.5, while that for TRAB with the $\mathrm{B} 40-100$ membrane, the final $\mathrm{pH}$ increased to 7.1. This observation indicated that increasing the IEC likely enhanced the $\mathrm{OH}^{-}$anion transfer rate through the AEM, resulting in a higher formation of $\mathrm{NH}_{3}$ in the cathode chamber which led to an increased unfavorable chemical consumption of copper ions (Eqns. S2-S5) instead of the electrochemical depletion $\left(\mathrm{Cu}^{2+} \rightarrow \mathrm{Cu}^{0}\right)$. Therefore, for a long experiment such as complete 
discharge to produce electrical energy, the benefit of a lower membrane resistance (i.e. a lower cell ohmic resistance) was likely offset by a higher IEC (i.e. a higher self-discharge rate).

The copper consumption with power generation, and the cathode coulombic efficiencies were measured to further investigate the impact of the membrane IEC on TRAB performance. The fabricated membrane with a higher IEC (B40) had the lowest copper electrochemical consumption of CEC $=47 \pm 10 \%$. The lowest CEC was obtained by the membrane with the highest IEC and the lowest thickness (B40-50; CEC of 29\%). The CEC increased to 85\%, which was $10 \%$ higher than the Selemion, for the membrane with the lowest IEC and the greatest thickness (B25-150; Figure 7). The CCE, which is the ratio of the produced current to the theoretical amount of current based on the change in mass of the cathode electrode, quantifies the relative importance of the $\mathrm{Cu}^{2+}$ electrodeposition reaction compared to other possible side electrochemical reactions $[16,20]$. A CCE of $67 \pm 8 \%$ was achieved using the B40 (high IEC) AEMs, while the B25 membranes (low IEC) had a CCE of $97 \pm 2 \%$. The highest CCE of $98 \pm$ $1 \%$ was obtained using the B25-100 membrane, which was 5\% higher than the Selemion (Figure 7). 


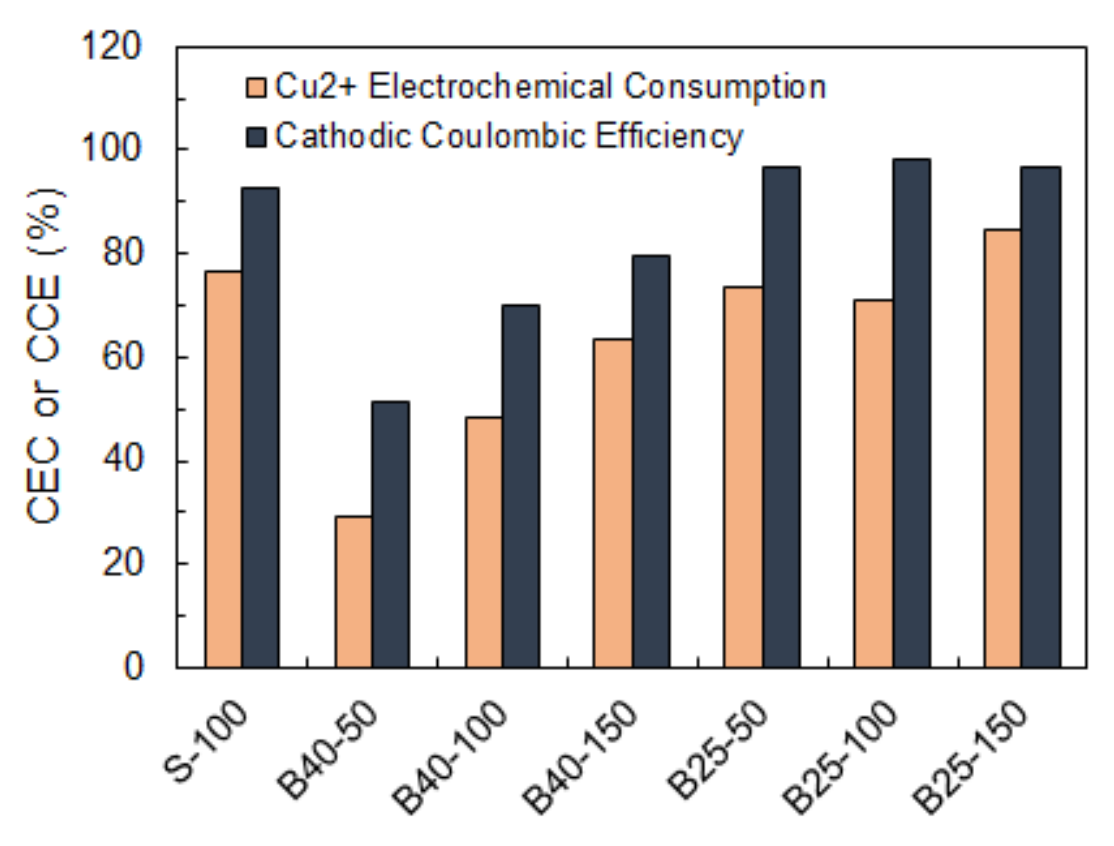

Figure 7. Copper ion electrochemical consumption and cathodic coulombic efficiencies of TRABs with different AEMs.

The changes in the CECs and CCEs for different membranes can be understood by considering the impacts of the membrane IECs on ion transfer. Membranes with a higher IEC allow a higher transfer of $\mathrm{OH}^{-}$, resulting in a higher formation of ammonia in the catholyte (Eqn. S1). The formed ammonia can chemically consume $\mathrm{Cu}^{2+}$, leading to a lowering of the CEC and TRAB performance in terms of energy density. In addition, using the B40-50 membrane (the highest IEC and the lowest thickness) would allow the highest $\mathrm{OH}^{-}$transfer, and consequently, the highest rate of $\mathrm{Cu}\left(\mathrm{NH}_{3}\right)_{4}{ }^{2+}$ formation in the cathode, resulting in $\mathrm{Cu}(\mathrm{OH})_{2}$ blue precipitates due to the unwanted side reaction $\mathrm{Cu}\left(\mathrm{NH}_{3}\right)_{4}{ }^{2+}+4 \mathrm{H}_{2} \mathrm{O} \rightarrow \mathrm{Cu}(\mathrm{OH})_{2}$ (s) $+2 \mathrm{NH}_{3} \cdot \mathrm{H}_{2} \mathrm{O}+2 \mathrm{NH}_{4}{ }^{+}$ [16]. The blue precipitates were visually observed just for the B40-50 membrane system, mainly due to a relatively high concentration of the formed $\mathrm{Cu}\left(\mathrm{NH}_{3}\right)_{4}{ }^{2+}$. The positively charged copper amine complex can be also reduced according to the reactions 6 and 7, resulting in lowering of 
the CCE $[35,36]$. This improvement in the CEC and CCE by decreasing the IEC and increasing the thickness further explained the highest energy production of B25-150 AEM.

$$
\begin{aligned}
& \mathrm{Cu}\left(\mathrm{NH}_{3}\right)_{4}{ }^{2+}{ }_{(\mathrm{aq})}+\mathrm{e}^{-} \rightarrow \mathrm{Cu}\left(\mathrm{NH}_{3}\right)_{4}{ }^{+}{ }_{(\mathrm{aq})} \\
& \mathrm{Cu}\left(\mathrm{NH}_{3}\right)_{4}{ }^{2+}{ }_{(\mathrm{aq})}+\mathrm{e}^{-} \rightarrow \mathrm{Cu}\left(\mathrm{NH}_{3}\right)_{2}{ }^{+}{ }_{(\mathrm{aq})}+2 \mathrm{NH}_{3} \text { (aq) }
\end{aligned}
$$

\subsection{Waste heat to electricity conversion efficiency}

The thermal efficiency reflected the conversion efficiency of low grade waste heat as electrical

power. In the TRAB, low grade waste heat $\left(<100{ }^{\circ} \mathrm{C}\right)$ was used to recharge the battery by separating ammonia from the anolyte effluent and re-dissolving it in the catholyte. The heat required for electrolyte regeneration was evaluated based on the heat requirements for a distillation column with a reboiler temperature of $70.4^{\circ} \mathrm{C}$ and condenser temperature of $43.3^{\circ} \mathrm{C}$, similar to our previous investigations $[16,19,20]$. Thermal efficiency followed the same trend as energy densities with respect to the thickness and IEC, with the highest efficiency of $0.97 \%$ for B25-150 (Table 2). 
Table 2. Comparison of the thermal energy efficiency and that relative to the Carnot efficacy of the previously developed waste-heat-to-electricity systems, and the thermally regenerative battery assembled with Selemion or $\mathrm{Bx}(\mathrm{x}=25,40)$ AEM.

\begin{tabular}{|c|c|c|c|c|}
\hline \multirow{2}{*}{$\begin{array}{c}\text { System } \\
\text { Temperature } \\
\text { Difference } \\
\left({ }^{\circ} \mathrm{C}\right)\end{array}$} & \multicolumn{2}{|c|}{ Efficiencies (\%) } & \multirow{2}{*}{ Reference } \\
\cline { 3 - 4 } & Thermal & $\begin{array}{c}\text { Relative to } \\
\text { Carnot }\end{array}$ & \\
\hline $\begin{array}{c}\text { carbon multi-walled } \\
\text { nanotube (MWNT) } \\
\begin{array}{c}\text { thermoelectrochemical } \\
\text { cell }\end{array}\end{array}$ & 60 & 0.25 & 1.4 & [37] \\
\hline $\begin{array}{c}\text { carbon single-walled } \\
\text { nanotube }\end{array}$ & 31 & NA & 2.63 & [38] \\
$\begin{array}{c}\text { (SWNT)/reduced } \\
\text { graphene oxide (rGO) } \\
\text { composite electrode }\end{array}$ & 51 & NA & 3.95 & [39] \\
\hline $\begin{array}{c}\text { carbon nanotube } \\
\text { aerogel-based } \\
\text { thermoelectrochemical } \\
\text { cell }\end{array}$ & 47 & 0.86 & 6.2 & This study \\
\hline Selemion-based TRAB & 47 & $0.76-0.93$ & $5.5-6.8$ & This study \\
\hline B40-based TRABs & 47 & $0.89-0.97$ & $6.5-7.0$ & This study \\
\hline B25-based TRABs & 47 & & & \\
\hline
\end{tabular}

\subsection{Comparison of performance with other systems}

The maximum power densities achieved here varied from $55 \mathrm{~W} \mathrm{~m}^{-2}$ to $106 \mathrm{~W} \mathrm{~m}^{-2}$-electrode was substantially higher than those obtained by the other waste heat-to-electricity systems $(0.5-6.6 \mathrm{~W}$ $\mathrm{m}^{-2}$ ) [37-39]. In addition, the TRAB with the B25-150 membrane was calculated to have a Carnot efficiency of $7.0 \%$, which was higher than the Selemion TRAB (6.2\%) and 1.8 times the highest previously reported value of $3.95 \%$ for a thermoelectrochemical cell operated with a 51 ${ }^{\circ} \mathrm{C}$ temperature difference between the carbon nanotube electrodes (Table 2) [39].

\subsection{Synthesized membrane stability and durability}

The acidic and alkaline stability of the fabricated membranes with different IEC were determined by polarization tests following immersion of the membranes in low $\mathrm{pH}$ catholyte or high $\mathrm{pH}$ 
anolyte solutions at room temperature. The results of the polarization tests for the acid soaked membranes showed 9\% (B40) and 6\% (B25) improvement in power production (Figure 8a). For the alkaline stability tests, both membranes illustrated no significant change ( $<1 \%$ difference) in maximum power density, in good agreement with previous studies that have shown high alkaline stability of both the BTMA head group and the polymer backbone $[40,41]$. The durability of the BTMA-based membrane was also determined by storing a dry sample inside a constant temperature room for a period of one year. The polarization result showed that the maximum power density decreased less than $9 \%$ after one year, confirming that the fabricated membranes were durable in storage (Figure 8b). In addition, no visual structural deformations, such as folding or cracking, were observed (Figure S5). 

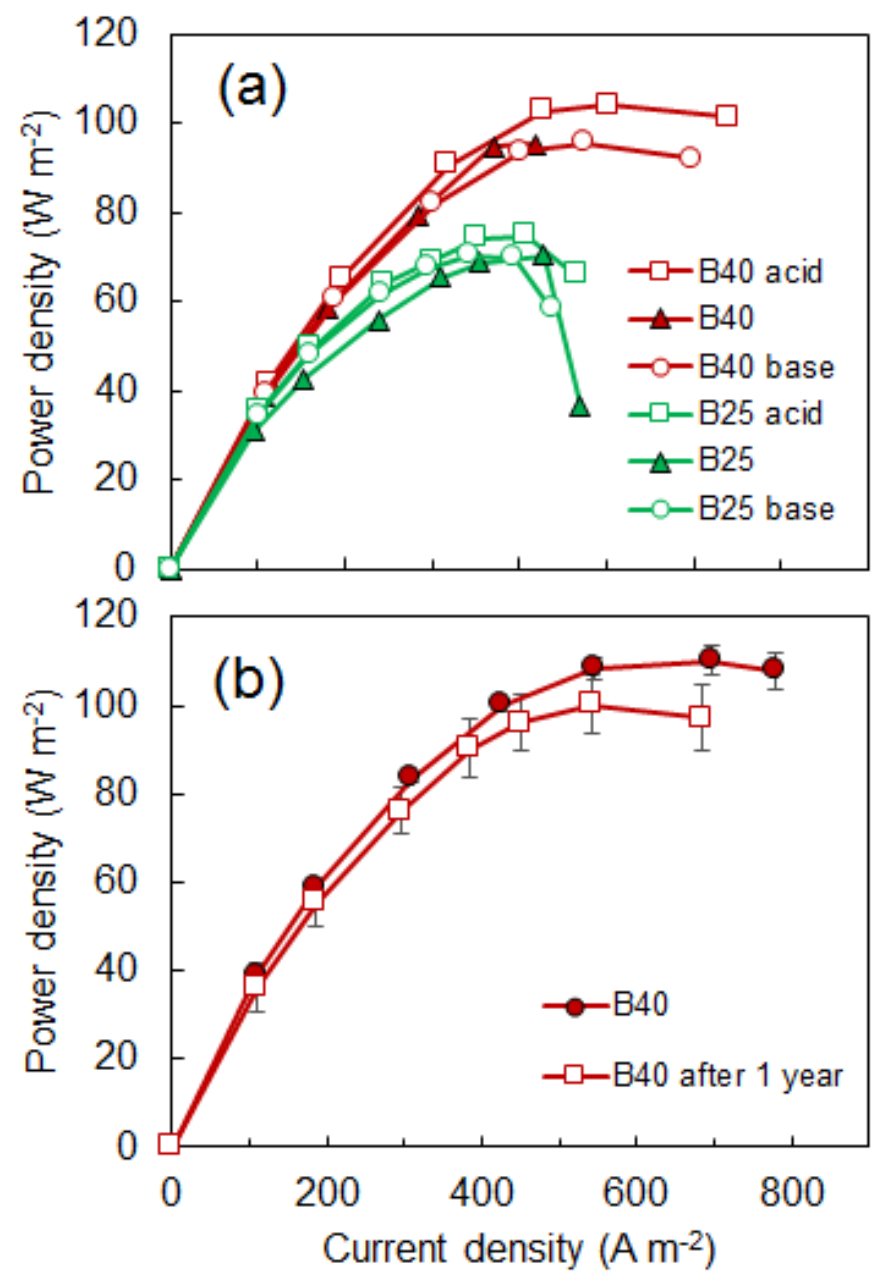

Figure 8. Power densities of TRABs operated with (a) acid soaked, alkaline soaked AEMs with a thickness of $100 \mu \mathrm{m}$, (b) B40-50 AEM kept dry for a period of one year.

\section{Conclusions}

TRAB performance in terms of power and energy density, and the overall waste heat-toelectricity conversion efficiency was enhanced by using a BTMA PPO-based AEM. An improvement of $31 \%$ in power density, and $13 \%$ in energy density was achieved using these new AEMs. The power density was primarily a function of the membrane resistance, while the energy density was a function of the membrane IEC. The TRAB with the fabricated membranes also showed a lower rate of cell self-discharge compared to the commercial Selemion membrane 
(11\% enhancement). The overall thermal efficiency was $\sim 1 \%$, with a $7 \%$ efficiency relative to the Carnot efficiency for a TRAB operated with the B25-150 membrane.

\section{Acknowledgments}

The research was supported by awards from the National Science Foundation (CBET-1464891) and the European Copper Institute (WO 16038).

\section{References}

[1] S. Chu, A. Majumdar, Nature 488 (2012) 294-303.

[2] C. Forman, I.K. Muritala, R. Pardemann, B. Meyer, Renew. Sust. Energ. Rev. 57 (2016) 1568-1579.

[3] M.I. Hoffert, K. Caldeira, G. Benford, D.R. Criswell, C. Green, H. Herzog, A.K. Jain, H.S. Kheshgi, K.S. Lackner, J.S. Lewis, H.D. Lightfoot, W. Manheimer, J.C. Mankins, M.E. Mauel, L.J. Perkins, M.E. Schlesinger, T. Volk, T.M.L. Wigley, Science 298 (2002) 981-987.

[4] I. Johnson, T. William, W. Choate, A.A. Davidson, (2008).

[5] Y. Kim, J. Kim, S. Yamanaka, A. Nakajima, T. Ogawa, T. Serizawa, H. Tanaka, M. Baba, T. Fukuda, K. Yoshii, M. Takeda, N. Yamada, T. Nakayama, K. Niihara, Adv. Energy Mater. 5 (2015) 6.

[6] A.P. Straub, N.Y. Yip, S. Lin, J. Lee, M. Elimelech, Nat. Energy 1 (2016) 16090.

[7] A. Carati, M. Marino, D. Brogioli, Energy 93, Part 1 (2015) 984-993.

[8] X. Niu, J.L. Yu, S.Z. Wang, J. Power Sources 188 (2009) 621-626.

[9] S.B. Riffat, X.L. Ma, Appl. Therm. Eng. 23 (2003) 913-935.

[10] C. Amaral, C. Brandao, E.V. Sempels, F.J. Lesage, J. Power Sources 272 (2014) 672-680.

[11] L.E. Bell, Science 321 (2008) 1457-1461.

[12] E.H.B. Anari, M. Romano, W.X. Teh, J.J. Black, E. Jiang, J. Chen, T.Q. To, J. Panchompoo, L. Aldous, Chem. Commun. 52 (2016) 745-748.

[13] M.A. Lazar, D. Al-Masri, D.R. MacFarlane, J.M. Pringle, Phys. Chem. Chem. Phys. 18 (2016) 14041410.

[14] X. Zhu, T. Kim, M. Rahimi, C. Gorski, B. Logan, ChemSusChem (2016) in press.

[15] T.I. Quickenden, Y. Mua, J. Electrochem. Soc. 142 (1995) 3985-3994.

[16] F. Zhang, J. Liu, W. Yang, B.E. Logan, Energy Environ. Sci. 8 (2015) 343-349.

[17] A.J. Bard, R. Parsons, J. Jordan, Standard potentials in aqueous solution, Taylor \& Francis, 1985.

[18] T. Kim, M. Rahimi, B.E. Logan, C.A. Gorski, ChemSusChem 9 (2016) 981-988.

[19] X. Zhu, M. Rahimi, C.A. Gorski, B. Logan, ChemSusChem 9 (2016) 873-879.

[20] F. Zhang, N. LaBarge, W. Yang, J. Liu, B.E. Logan, ChemSusChem 8 (2015) 1043-1048.

[21] M. Rahimi, Z. Schoener, X. Zhu, F. Zhang, C.A. Gorski, B.E. Logan, J. Hazard. Mater. 322 (2017) 551556.

[22] J. Pan, L. Zhu, J.J. Han, M.A. Hickner, Chem. Mater. 27 (2015) 6689-6698.

[23] J.R. Varcoe, P. Atanassov, D.R. Dekel, A.M. Herring, M.A. Hickner, P.A. Kohl, A.R. Kucernak, W.E. Mustain, K. Nijmeijer, K. Scott, T.W. Xu, L. Zhuang, Energy Environ. Sci. 7 (2014) 3135-3191.

[24] N.W. Li, Y.J. Leng, M.A. Hickner, C.Y. Wang, J. Am. Chem. Soc. 135 (2013) 10124-10133. 
[25] A.D. Mohanty, Y.B. Lee, L. Zhu, M.A. Hickner, C. Bae, Macromolecules 47 (2014) 1973-1980.

[26] L. Zhu, J. Pan, C.M. Christensen, B.C. Lin, M.A. Hickner, Macromolecules 49 (2016) 3300-3309.

[27] L. Zhu, J. Pan, Y. Wang, J. Han, L. Zhuang, M.A. Hickner, Macromolecules 49 (2016) 815-824.

[28] L. Zhu, T.J. Zimudzi, N. Li, J. Pan, B. Lin, M.A. Hickner, Polym. Chem. 7 (2016) 2464-2475.

[29] T. Kim, M. Rahimi, B.E. Logan, C.A. Gorski, Environ. Sci. Technol. 50 (2016) 9791-9797.

[30] X.T. Le, T.H. Bui, P. Viel, T. Berthelot, S. Palacin, J. Membr. Sci. 340 (2009) 133-140.

[31] X.T. Le, J. Colloid Interface Sci. 325 (2008) 215-222.

[32] C.X. Lin, Y.Z. Zhuo, A.N. Lai, Q.G. Zhang, A.M. Zhu, M.L. Ye, Q.L. Liu, J. Membr. Sci. 513 (2016) 206216.

[33] G.M. Geise, M.A. Hickner, B.E. Logan, ACS Appl. Mater. Interfaces 5 (2013) 10294-10301.

[34] G.M. Geise, D.R. Paul, B.D. Freeman, Prog. Polym. Sci. 39 (2014) 1-42.

[35] F. Habashi, Ber. Bunsen Ges. Phys. Chem. 67 (1963) 402-406.

[36] D. Grujicic, B. Pesic, Electrochim. Acta 50 (2005) 4426-4443.

[37] R. Hu, B.A. Cola, N. Haram, J.N. Barisci, S. Lee, S. Stoughton, G. Wallace, C. Too, M. Thomas, A. Gestos, M.E.d. Cruz, J.P. Ferraris, A.A. Zakhidov, R.H. Baughman, Nano Lett. 10 (2010) 838-846.

[38] M.S. Romano, N. Li, D. Antiohos, J.M. Razal, A. Nattestad, S. Beirne, S. Fang, Y. Chen, R. Jalili, G.G. Wallace, R. Baughman, J. Chen, Adv. Mater. 25 (2013) 6602-6606.

[39] H. Im, T. Kim, H. Song, J. Choi, J.S. Park, R. Ovalle-Robles, H.D. Yang, K.D. Kihm, R.H. Baughman, H.H. Lee, T.J. Kang, Y.H. Kim, Nat. Commun. 7 (2016).

[40] D. Chen, M.A. Hickner, ACS Appl. Mater. Interfaces 4 (2012) 5775-5781.

[41] H. Long, K. Kim, B.S. Pivovar, J. Phys. Chem. C 116 (2012) 9419-9426. 
Table 1. IEC and water uptake of the Selemion compared to that of the B25 and B40 AEMs, all with a thickness of $100 \mu \mathrm{m}$.

\begin{tabular}{|c|c|c|}
\hline Sample & $\begin{array}{c}\text { IEC } \\
\left(\mathbf{m m o l ~}^{\mathbf{- 1}}\right)\end{array}$ & Water uptake (wt \%) \\
\hline Selemion & 1.93 & $20 \pm 2$ \\
\hline B25 & 1.82 & $63 \pm 4$ \\
\hline B40 & 2.04 & $80 \pm 7$ \\
\hline
\end{tabular}


Table 2. Comparison of the thermal energy efficiency and that relative to the Carnot efficacy of the previously developed waste-heat-to-electricity systems, and the thermally regenerative battery assembled with Selemion or $\mathrm{Bx}(\mathrm{x}=25,40)$ AEM.

\begin{tabular}{|c|c|c|c|c|}
\hline \multirow{2}{*}{ System } & \multirow{2}{*}{$\begin{array}{l}\text { Temperature } \\
\text { Difference } \\
\left({ }^{\circ} \mathrm{C}\right)\end{array}$} & \multicolumn{2}{|c|}{ Efficiencies (\%) } & \multirow{2}{*}{ Reference } \\
\hline & & Thermal & $\begin{array}{c}\text { Relative to } \\
\text { Carnot }\end{array}$ & \\
\hline $\begin{array}{c}\text { carbon multi-walled } \\
\text { nanotube (MWNT) } \\
\text { thermoelectrochemical } \\
\text { cell }\end{array}$ & 60 & 0.25 & 1.4 & {$[36]$} \\
\hline $\begin{array}{c}\text { carbon single-walled } \\
\text { nanotube } \\
\text { (SWNT)/reduced } \\
\text { graphene oxide (rGO) } \\
\text { composite electrode }\end{array}$ & 31 & NA & 2.63 & {$[37]$} \\
\hline $\begin{array}{c}\text { carbon nanotube } \\
\text { aerogel-based } \\
\text { thermoelectrochemical } \\
\text { cell }\end{array}$ & 51 & NA & 3.95 & {$[38]$} \\
\hline Selemion-based TRAB & 47 & 0.86 & 6.2 & This study \\
\hline B40-based TRABs & 47 & $0.76-0.93$ & $5.5-6.8$ & This study \\
\hline B25-based TRABs & 47 & $0.89-0.97$ & $6.5-7.0$ & This study \\
\hline
\end{tabular}

